\title{
Experimental Study of Axially Compressed Cold Formed Steel Channel Columns
}

\author{
Sreedhar Kalavagunta ${ }^{1 *}$, Sivakumar Naganathan ${ }^{2}$ and Kamal Nasharuddin Bin Mustapha ${ }^{3}$ \\ 1 Bentley Systems (Singapore) Pvt. Ltd. 30 Raffles Place, \#12-02/30, \\ Chevron House, Singapore; sreedhar.bala@gmail.com \\ ${ }^{2}$ Civil Engineering, Universiti Tenaga Nasional, Jalan IKRAM-UNITEN, 43000, \\ Kajang, Selangor, Malaysia; SivaN@uniten.edu.my \\ ${ }^{3}$ Civil Engineering, Universiti Tenaga Nasional, Jalan IKRAM-UNITEN, 43000, \\ Kajang, Selangor, Malaysia; kamal@uniten.edu.my
}

\begin{abstract}
Analysis and design of axially compressed cold formed steel channel section presented in this paper was conducted through experimental study, design based on British standards and North American Specification for the design of cold-formed steel structural members. More than 18 laboratory experiments were undertaken first on these steel channel columns under axial compression. A series of parametric studies were also carried out by varying the thickness and column length. All of these columns failed by local and distortional buckling. The test results were compared with American (AISI-2007) and British Standards (BS5950-Part5) for the design of cold-formed steel structural members. The details of these investigation and the outcomes are presented in this paper.
\end{abstract}

Keywords: Cold Formed Channel Sections, Axially Compressed Members, BS5950, Effective Width Method, Direct Strength Method.

\section{Introduction}

The use of Cold Formed Steel (CFS) structures have increased rapidly in recent years due to significant improvements in manufacturing technologies. CFS members are made from steel sheets and are formed to different shapes either through press-braking sheared form sheets or coils or more commonly, by rolling done at room temperature. CFS sections are typically thin-walled with a thickness ranging from $0.4 \mathrm{~mm}$ to $6.5 \mathrm{~mm}$ [1]. The most commonly used shapes of CFS member are lipped channel, $\mathrm{Z}$ and C shapes, hat and tubular sections.

The CFS sections offer one of the highest load capacityto-weight ratios among the various structural components currently in the market. It also offers economy in production, transportation and handling. CFS sections with edge stiffened flanges have three types buckling specifically local buckling, distortional buckling and Euler's buckling (flexural or flexural-torsional), generally called as global buckling $[2,3]$. Local buckling is normally defined as a mode that involves deformation of some or all of the individual plate elements forming a cross section, possibly involving sympathetic deformations of adjacent plate elements. Distortional buckling involves deformations of the junctions between plate elements. Several studies have been conducted on cold formed steel buckling modes [4-11] by various authors.

\section{Cold Formed Steel Design Methods}

Currently, two basic design methods of CFS members, the traditional Effective Width Method (EWM) and the Direct Strength Method (DSM) are formally available. Until
*Corresponding author:

Sreedhar Kalavagunta (sreedhar.bala@gmail.com) 
recently, the conventional EWM has been the only way to estimate the member strength for over 60 years. However, as structural shapes become more complex with additional lips and intermediate stiffeners, the accurate computation of the effective widths of individual elements of the complex shapes becomes more difficult and inaccurate. In order to overwhelm this problem, the DSM has been developed by Shafer et al.[3] and further studied by Hancock et al. [12].

\subsection{The Effective Width Method}

The Effective Width Method, introduced by Von Karman et al. [13] and subsequently modified by Winter [14], has been the primary design approach for the CFS members in the North American Specification for the Design of ColdFormed Steel Structural Members (AISI) Specifications including the latest edition of AISI [15]. However, the EWM does not have sufficient procedures for predicting the distortional buckling failure. When sections become more complex and optimized, with additional edges and/ or intermediate stiffeners, the computation of the effective widths become extremely complicated and time consuming.

\subsection{The Direct Strength Design Method}

The Direct Strength Design Method [16] is initially proposed in 1988 and has been adopted by the North American Cold-Formed Steel Specifications in 2004 as an alternative to the traditional EWM to estimate the compression and the flexural member strength, which can consider an interaction of local or distortional and overall buckling modes. This method does not require effective width calculations or iteration, but instead uses gross properties and the elastic buckling behavior of cross section to calculate section or member strength. Schafer [17] presented the first state-ofthe-art review in the literature on the use of the 'The DSM of cold-Formed Steel member design'. Much work remains for the continued development of the cold-formed steel design methods, but the efforts of many research groups around the world are working continuously. Recently, Yu et al. [18] proposed a design method based on the EWM for determining the nominal distortional buckling strength of typical cold-formed steel $\mathrm{C}$ and $\mathrm{Z}$ sections. This method offers the same level of accuracy and reliability as the DSM, Ganesan et al. [19] studied on LRFD resistance factor for coldformed steel compression members, Nguyen et al. [20] investigated on compression tests of cold-formed plain and dimpled steel columns, the results showed that the buck- ling and ultimate strengths of dimpled columns where up to $33 \%$ and $26 \%$ greater than plain steel columns respectively. Goodarzian et al. [21] investigated on optimization using genetic algorithms was carried out and the cross section's parameters were obtained.

In this paper experimental investigation conducted a series of compression tests on industrial standard cold formed steel C sections and theoretically designed with British 5950-5 and AISI specifications.

\section{Material Properties and Test Specimens}

Axial compression tests were performed on C-section, the setup and the test rig of this section are shown in Figure 1(a). One low voltage displacement transducer is placed at mid of C-section flange to observe vertical deflection of C-Section. Lysaght high tensile C-Lipped channels Figure 1(b), is selected for this test, yield stress up to 550 Mpa and is designed in accordance to BS5950-5 and AISI specifications. Lysaght C-lipped channel with varies depth and thickness from $75 \mathrm{~mm}$ to $100 \mathrm{~mm}$ depth and 0.6 to 1 mm thickness.

Each specimen was cut to final length, ranging from $500 \mathrm{~mm}$ to $700 \mathrm{~mm}$ depending on the test group that the specimen belonged to. To ensure that the two supporting ends were parallel to each other and perpendicular to the loading axis, they were wire eroded normal to the loading axis. This ensured full contact between specimen and steel end plates. The column length was greater than three times the greatest flat width of the section and its length/radius of gyration in the direction of the least radius of gyration was kept to less than 50 . This is done to prevent failure of the column due to column flexural buckling rather than local buckling (V.B.N20, 22-24].

Several test data of plain column specimens were used and the experimental critical buckling load was determined Figure 2. The test results were compared with the predicted values based on theoretical methods EWM and DSM. The measured cross section dimensions and material properties presented in Table 1.

\section{Analytical Investigation}

The theoretical compression capacity loads was obtained based on specifications BS5950-5 for EWM and AISI for DSM. The theoretical ultimate load of a section was 

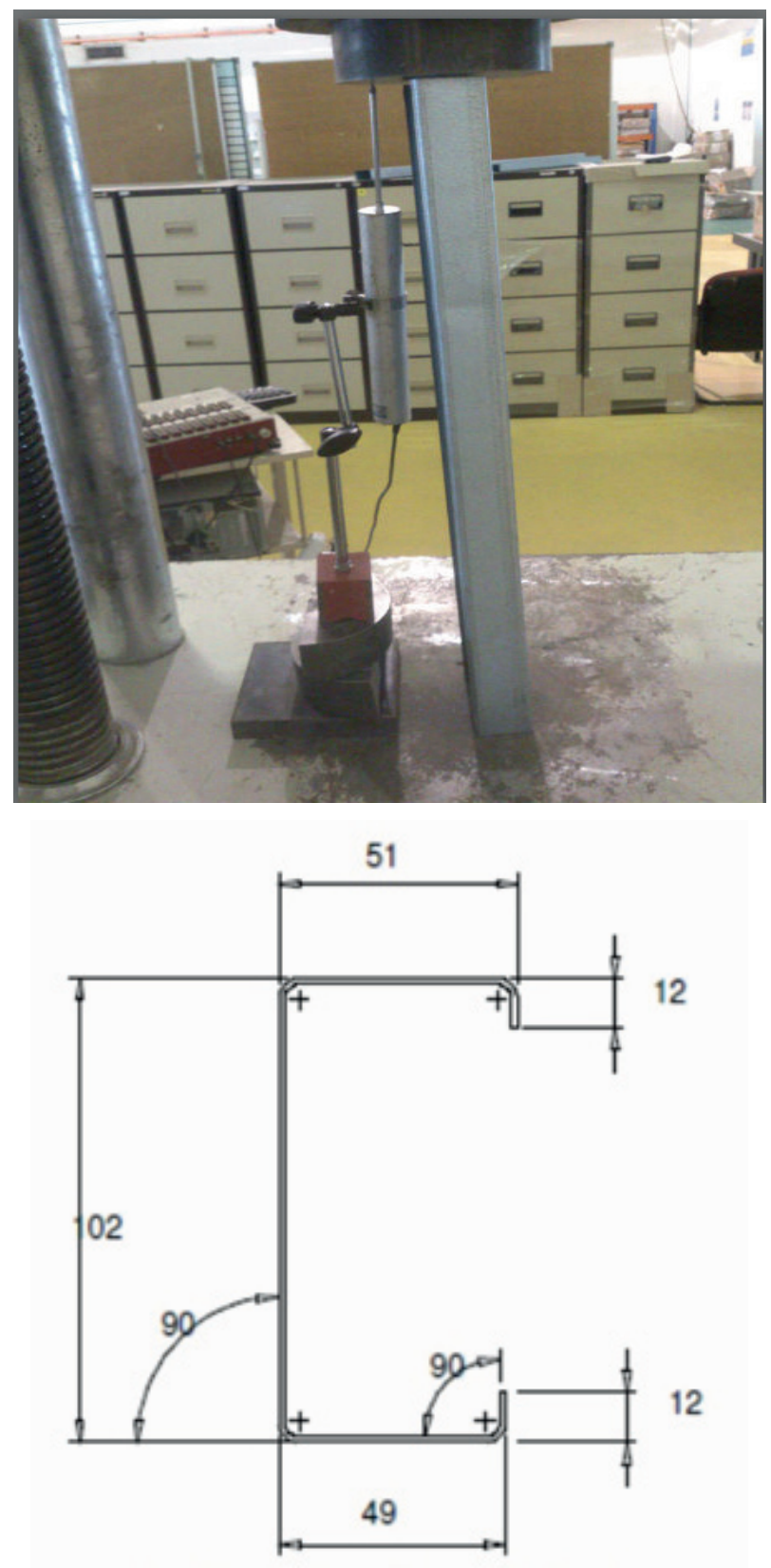

Figure 1. (a) Test Set up (b) Section dimension for C100 section.

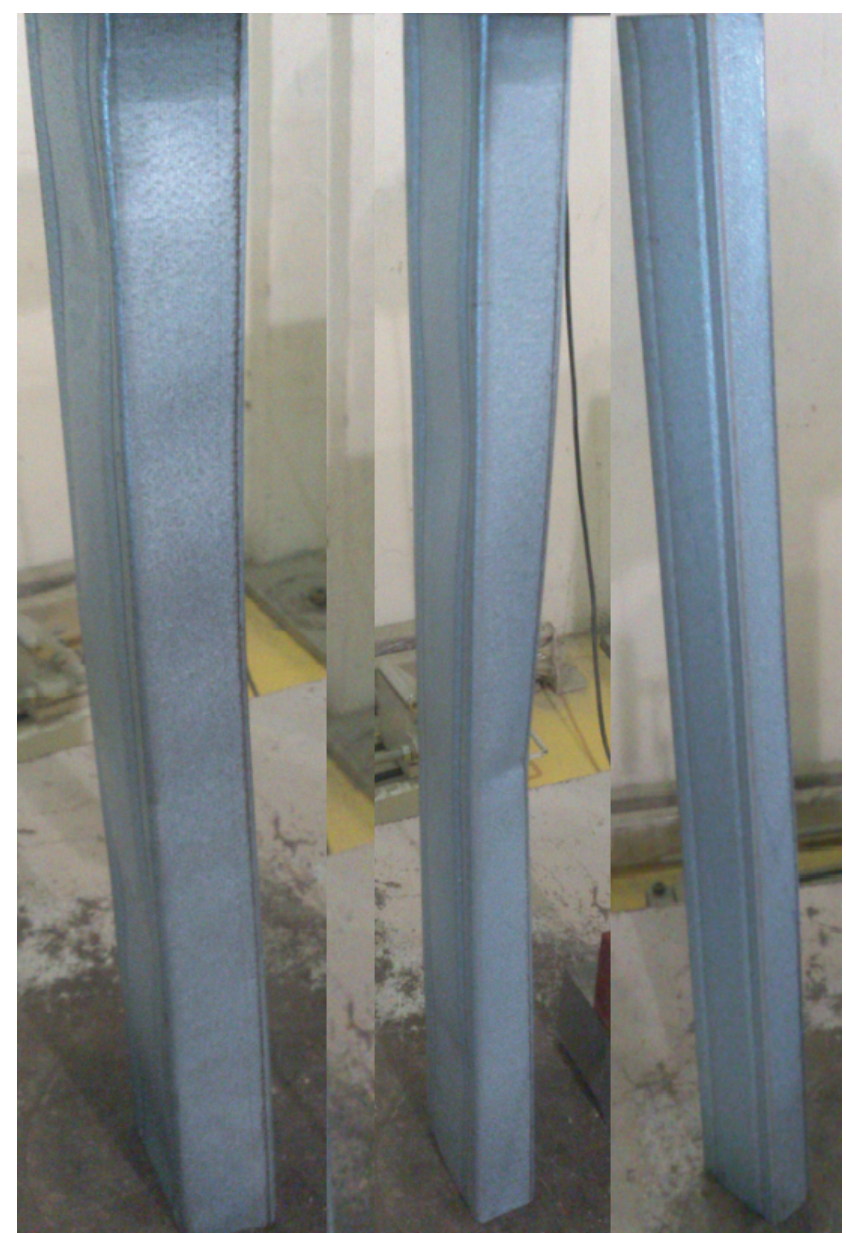

Figure 2. Failure modes shapes.

determined from EWM described in BS5950-5, some semiempirical formulae as follows:

The ultimate axial compression load of single symmetric composite shapes of open cross section not subject to torsional-flexural buckling determined based on Eq.(1)

$$
P_{c}^{\prime}=\frac{M_{c} P_{c}}{\left(M_{c}+P_{c} e_{s}\right)}
$$

Table 1. Section dimensions and properties

\begin{tabular}{|c|c|c|c|c|c|c|c|c|c|}
\hline Component & $\begin{array}{c}\text { Thickness } \\
(\mathrm{mm})\end{array}$ & $\begin{array}{l}\text { Yield } \\
\text { Stress } \\
(\mathrm{Mpa}) \\
\end{array}$ & $\begin{array}{c}\text { Area } \\
\left(\mathrm{mm}^{2}\right)\end{array}$ & $\begin{array}{l}\mathrm{I}_{\mathrm{xx}} \mathrm{x} 10^{4} \\
\left(\mathrm{~mm}^{4}\right) \\
\end{array}$ & $\begin{array}{l}\mathrm{I}_{\mathrm{yy}} \mathrm{x} 10^{4} \\
\left(\mathrm{~mm}^{4}\right)\end{array}$ & $\begin{array}{c}\text { Section } \\
\text { Modulus, } \\
\mathrm{Z}_{\mathrm{x}} \mathrm{x} 10^{3} \\
\left(\mathrm{~mm}^{3}\right) \\
\end{array}$ & $\begin{array}{c}\text { Section } \\
\text { Modulus, } \\
\mathrm{Z}_{\mathrm{y}} \times 10^{3} \\
\left(\mathrm{~mm}^{3}\right) \\
\end{array}$ & $\begin{array}{c}\text { Radius of } \\
\text { Gyration } \\
\mathrm{R}_{\mathrm{x}}(\mathrm{mm})\end{array}$ & $\begin{array}{l}\text { Radius of } \\
\text { Gyration } \\
\mathrm{R}_{\mathrm{y}}(\mathrm{mm}) \\
\end{array}$ \\
\hline C7510 & 1 & 550 & 137 & 12.2 & 2.85 & 3.25 & 1.02 & 29.84 & 12.67 \\
\hline C7512 & 1.2 & 550 & 204 & 18.9 & 5.2 & 5.14 & 1.84 & 30.43 & 15.96 \\
\hline C100 & 1 & 550 & 216 & 36.4 & 7.55 & 7.13 & 2.19 & 41.1 & 18.7 \\
\hline
\end{tabular}


Where,

$M_{c}$ is the moment capacity determined in accordance with section 5.2.2.

$P_{c}^{\prime}$ is the buckling resistance under axis load determined in accordance with section 6.2.3.

$e_{s}$ is the distance between the geometric neutral axis of the gross cross-section assumed as unity.

Moment capacity $M_{c}$, determined on the basis of a limiting compressive stress in the webs, $p_{o}$ as per section 5.2.2.2.

$$
p_{o}=\left\{1.13-0.0019 \frac{D_{w}}{t_{t}}\left(\frac{Y_{s}}{280}\right)^{\frac{1}{2}}\right\} p_{y} \leq p_{y}
$$

where,

$D_{w}$ is the section depth or twice the depth of the compression zone.

$Y_{s}$ is the material yield strength in Newton per square millimeter $\left(\mathrm{N} / \mathrm{mm}^{2}\right)$

$t$ is the web thickness in millimeters ( $\mathrm{mm}$ ).

$p_{y}$ is the design strength in Newton per square millimeter $\left(\mathrm{N} / \mathrm{mm}^{2}\right)$

The buckling resistance under axial load, $P_{c}$, may be obtained from the following:

$$
P_{c}=\frac{P_{E} P_{c s}}{\varnothing+\sqrt{\varnothing^{2}-P_{E} P_{c s}}}
$$

where,

$$
\varnothing=\frac{P_{C S}+(1+\eta) P_{E}}{2}
$$

$P_{C S}$ is the short strut capacity and is equal to $A_{e f f} p_{y}$

$p_{y}$ is the design strength

$A_{e f f}$ is calculated as per table 5-BS5950-5

$P_{E}$ is the minimum elastic flexural buckling load and is equal to $\frac{\pi^{2} E_{c} I}{L_{E}^{2}}$

$E c$ is the modulus of elasticity of composite section.

I is the second moment of area of the cross-section about the critical axis. $L_{E}$ is the effective length of the member about the critical axis. $\eta$ is the Perry coefficient, such that:

$$
\begin{aligned}
& \text { for } L_{E} / r \leq 20, \eta=0 \\
& \text { for } L_{E} / r>20, \eta=0.002\left(L_{E} / r-20\right)
\end{aligned}
$$

where,

$r$ is the radius of gyration of the gross cross-section corresponding to $P_{E}$

$$
P_{u}=A_{e f f} P_{c}^{\prime}
$$

$P_{u}$ is ultimate compression stress modified equation as per BS5950-5:1998 section 6.2.4

The experimental test results are also compared with capacities calculated according to AISI.

The compression capacity estimated based on AISI direct strength method.

Flexural, Torsional, or Torsional-Flexural Buckling $\left(\mathrm{P}_{\text {ne }}\right)$

$$
P_{n e}= \begin{cases}\left(0.658^{\lambda_{c}^{2}}\right) P_{y} & \lambda_{c} \leq 1.5 \\ \left(\frac{0.877}{\lambda_{c}^{2}}\right) & \lambda_{c}>1.5\end{cases}
$$

Where,

$$
\lambda_{c}=\sqrt{P_{y} / P_{c r e}}
$$

$\mathrm{P}_{\text {cre }}=$ Minimum of the critical elastic column buckling load in flexural, torsional, or torsional-flexural buckling.

Local Buckling $\left(\mathrm{P}_{\mathrm{nl}}\right)$

$P_{n l}=\left\{\begin{array}{lll}P_{n e} & \lambda_{l} \leq 0.766 \\ {\left[1-0.15\left(\frac{P_{c r l}}{P_{n e}}\right)^{0.4}\right]\left(\frac{P_{c r l}}{P_{n e}}\right)^{0.4}} & P_{n e} & \lambda_{l}>0.766\end{array}\right.$

where,

$$
\lambda_{c}=\sqrt{P_{y} / P_{c r e}}
$$

$\mathrm{P}_{\text {crl }}=$ Criticaelastic local column buckling load.

Distortional Buckling $\left(\mathrm{P}_{\mathrm{nd}}\right)$

$$
P_{n d}= \begin{cases}P_{y} & \lambda_{d} \leq 0.561 \\ {\left[1-0.25\left(\frac{P_{c r d}}{P_{y}}\right)^{0.6}\right]\left(\frac{P_{\text {crd }}}{P_{y}}\right)^{0.6}} & P_{y} \lambda_{d}>0.561\end{cases}
$$

where,

$$
\lambda_{c d}=\sqrt{P_{y} / P_{c r d}}
$$

$P_{c r d}=$ Critical elastic distortional column buckling load.

The theoretical design loads determined from BS5950part5 and AISI specifications were compared with the experimental ultimate loads as shown in Table 2. The 
proposed ultimate capacity of cold formed steel sections based on Eq.4 and experimental results are plotted in Figure 3 were reasonable agreement is obtained. The experimental tests results of the columns and the theoretical results obtained from BS5950-part5 and AISI specifications are tabulated in Table 2 and Table 3.

\section{Conclusions}

Axial compression tests on cold-formed lipped channel sections were conducted. A total of 27 lipped channel specimens were tested. This paper has outlined two current approaches to the design of lipped channel sections using an extension to the DSM in AISI and EWM in BS5950-5 specifications as well as the test results. The DSM employs gross cross sectional area were as EWM fallows effective plate width for calculating cross section capacity. The experimental test results are very close to DSM and EWM methods.

\section{References}

1. Kalavagunta S, Naganathan S et al. (2012). Cold formed steel in construction: A review of research, challenges and opportunities, ASEA-SEC-1, Perth, 359-363.

Table 2. Axial Compression tests results : Experimental Vs BS5950-Part5 Theoretical

\begin{tabular}{|c|c|c|c|}
\hline Section & FY Mpa & $\begin{array}{l}\text { Ultimate Axial Compression } \\
\text { Capacity-Experimental-kN }\end{array}$ & $\begin{array}{l}\text { Ultimate Axial Compression } \\
\text { Capacity - Theoretical -kN }\end{array}$ \\
\hline $\mathrm{C} 7510 \times 500 \mathrm{~mm}$ & 550 & 57.97 & 51.98 \\
\hline $\mathrm{C} 7510 \times 600 \mathrm{~mm}$ & 550 & 57.88 & 51.82 \\
\hline $\mathrm{C} 7510 \times 700 \mathrm{~mm}$ & 550 & 56.75 & 51.27 \\
\hline $\mathrm{C} 7512 \times 500 \mathrm{~mm}$ & 550 & 72.65 & 66.75 \\
\hline $\mathrm{C} 7512 \times 600 \mathrm{~mm}$ & 550 & 71.08 & 66.51 \\
\hline $\mathrm{C} 7512 \times 700 \mathrm{~mm}$ & 550 & 69.5 & 65.80 \\
\hline $\mathrm{C} 10010 \times 500 \mathrm{~mm}$ & 550 & 68.5 & 59.98 \\
\hline $\mathrm{C} 10010 \times 600 \mathrm{~mm}$ & 550 & 67.9 & 59.86 \\
\hline $\mathrm{C} 10010 \times 700 \mathrm{~mm}$ & 550 & 66.9 & 59.72 \\
\hline
\end{tabular}

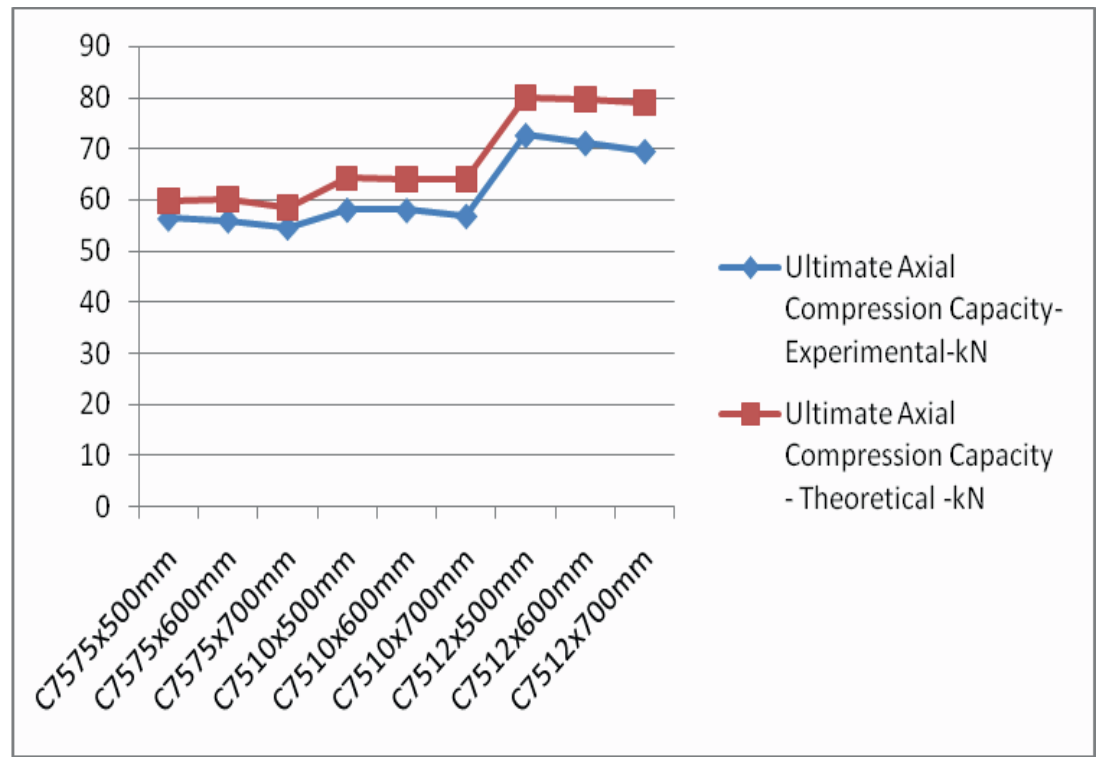

Figure 3. Graph Ultimate load - Experimental Vs Theoretical 
Table 3. Axial Compression tests results: Experimental Vs AISI Theoretical

\begin{tabular}{|c|c|c|c|}
\hline Section & FY Mpa & $\begin{array}{l}\text { Ultimate Axial Compression } \\
\text { Capacity-Experimental-kN }\end{array}$ & $\begin{array}{l}\text { Ultimate Axial Compression } \\
\text { Capacity - Theoretical -kN }\end{array}$ \\
\hline $\mathrm{C} 7510 \times 500 \mathrm{~mm}$ & 550 & 57.97 & 56.56 \\
\hline $\mathrm{C} 7510 \times 600 \mathrm{~mm}$ & 550 & 57.88 & 55.84 \\
\hline $\mathrm{C} 7510 \times 700 \mathrm{~mm}$ & 550 & 56.75 & 55.00 \\
\hline $\mathrm{C} 7512 \times 500 \mathrm{~mm}$ & 550 & 72.65 & 84.31 \\
\hline $\mathrm{C} 7512 \times 600 \mathrm{~mm}$ & 550 & 71.08 & 83.28 \\
\hline $\mathrm{C} 7512 \times 700 \mathrm{~mm}$ & 550 & 69.5 & 82.08 \\
\hline $\mathrm{C} 10010 \times 500 \mathrm{~mm}$ & 550 & 68.5 & 66.40 \\
\hline $\mathrm{C} 10010 \times 600 \mathrm{~mm}$ & 550 & 67.9 & 66.07 \\
\hline $\mathrm{C} 10010 \times 700 \mathrm{~mm}$ & 550 & 66.9 & 70.08 \\
\hline
\end{tabular}

2. Macdonald M, Heiyantuduwa M A et al. (2008). Recent development in the design of cold-formed steel members, Thin-Walled Structures, vol 46(7-9), 1047-1053.

3. Schafer B W, and Pekoz T (1998). Direct strength prediction of cold-formed steel members using numerical elastic buckling solutions, Thin-walled Structures, Shanmugam N E, et al., Ed, Amsterdam: Elsevier.

4. Haidarali M R, and Nethercot D A (2012). Local and distortional buckling of cold-formed steel beams with edge-stiffened flanges, Journal of Constructional Steel Research, vol 73, 31-42

5. Cheng S, Kim B et al. (2013). Lateral torsional buckling of cold-formed channel sections subject to combined compression and bending, Journal of Constructional Steel Research, vol 80, 174-180.

6. Yu C, and Schafer B W, (2003). Local buckling tests on cold-formed steel beams, Journal of Structural Engineering, ASCE, vol 129(12), 1596-1606.

7. Yu C, and Schafer B W (2006). Distortional buckling tests on cold-formed steel beams, Journal of Structural Engineering, ASCE, vol 132(4), 515-528.

8. LeeJandKimSE(2002).Lateralbucklinganalysisofthin-walled laminated channel-section beams, Composite Structures, vol 56(4), 391-399.

9. Seah L K and Khong P W (1990). Lateral-torsional buckling of channel beams, Journal Construction Steel Research, vol 17(4), 265-282.

10. Li L Y (2004). Lateral-torsion buckling of cold-formed zed-purlins partial-laterally restrained by metal sheeting, Thin-walled Structures, vol 42(7), 995-1011.

11. Schardt R (1994). Lateral torsional and distortional buckling of channel and hat-sections. Journal Construction Steel Research, vol 31(2/3), 243-265.
12. Hancock G J, Murray T M et al. (2001). Cold-formed Steel Structures to the AISI Specification, Marcel Dekker, Inc.

13. Von Karman T, Sechler E E, et al. (1932). The strength of thin plates in compression, Transactions ASME, vol 54, APM 5405, 53-57.

14. Winter G, (1947). Strength of thin steel compression flanges, Transactions of ASCE, vol 112, Paper no. 2305, 527.

15. American Iron and Steel Institute, (2007). AISI S100 North American specification for the design of cold-formed steel structural members, Washington, DC.

16. Schafer B W (2006). Designing Cold-Formed Steel using the Direct Strength Method, 18th International Specialty Conference on Cold-Formed Steel Structures, Orlando, Florida.

17. Schafer B W (2008). Review: The Direct Strength Method of cold-formed steel member design, Journal of Constructional Steel Research, vol 64, 766-778.

18. Yua C and Yan W (2011). Effective Width Method for determining distortional buckling strength of cold-formed steel flexural C and Z sections, Thin-walled Structures, vol 49(2), 233-238.

19. Ganesan K and Moen C D (2012). LRFD resistance factor for cold-formed steel compression members, Journal of Constructional Steel Research, vol 72, 261-266.

20. Nguyen V B, Wang C J et al. (2012). Compression tests of cold-formed plain and dimpled steel columns, Journal of Constructional Steel Research, vol 69(1), 20-29.

21. Goodarzian H, Hejazi S S, et al. (2011). Optimization of the cross section of car lift column under pressure load using genetic algorithms, Indian Journal of Science and Technology, vol 4(6), 622-626. 